Published in final edited form as:

Physiol Behav. 2007 December 5; 92(5): 781-789.

\title{
Regulation of $\mathrm{NaCl}$ solution intake and gastric emptying in adrenalectomized rats
}

\author{
Michael R. Bykowski ${ }^{1}$, James C. Smith ${ }^{2}$, and Edward M. Stricker ${ }^{1}$ \\ 1 Department of Neuroscience, University of Pittsburgh, Pittsburgh, PA 15260 \\ 2 Department of Psychology, Florida State University, Tallahassee, FL 32306
}

\begin{abstract}
Adrenalectomized (adrex) rats adaptively increase $\mathrm{NaCl}$ intake to compensate for the uncontrolled loss of $\mathrm{Na}^{+}$in urine due to the absence of aldosterone. After a period of $\mathrm{NaCl}$ deprivation, they ingest saline avidly but stop drinking before hyponatremia is repaired. The present experiments determined whether presystemic signals inhibit further $\mathrm{NaCl}$ intake, and whether gastric emptying of $\mathrm{Na}^{+}$is modulated according to the concentration of ingested $\mathrm{NaCl}$ solution. After overnight deprivation, adrex rats consumed $0.05 \mathrm{M}$ and $0.15 \mathrm{M} \mathrm{NaCl}$ at a maximally fast rate $(\sim 1.7 \mathrm{ml} / \mathrm{min})$ and emptied ingested fluid from the stomach at a slower but maximally fast rate $(\sim 1.1 \mathrm{ml} / \mathrm{min})$. When $0.30 \mathrm{M}$ $\mathrm{NaCl}$ was consumed instead, fluid intake still was maximally fast but gastric emptying slowed in proportion to concentration so that the emptying of $\mathrm{Na}^{+}$was comparable to that observed when 0.15 $\mathrm{M} \mathrm{NaCl}$ was ingested ( $\sim .13 \mathrm{meq} / \mathrm{min})$. When $0.50 \mathrm{M} \mathrm{NaCl}$ was consumed, intake slowed proportionately so that $\mathrm{Na}^{+}$consumption was comparable to that observed when $0.30 \mathrm{M} \mathrm{NaCl}$ was ingested $(\sim 0.5 \mathrm{meq} / \mathrm{min})$. $\mathrm{NaCl}$ intake appeared to be inhibited both by the concentration of saline emptied from the stomach and by the volume of ingested fluid in the stomach and small intestine. Gastric emptying also slowed proportionately when $0.50 \mathrm{M} \mathrm{NaCl}$ was consumed, as if the rats were regulating the delivery of $\mathrm{Na}^{+}$to the small intestine. These results suggest that adrex rats can detect the volume and concentration of ingested $\mathrm{NaCl}$ solution and integrate these two variables, and thereby modulate the rates of $\mathrm{Na}^{+}$intake and gastric emptying.
\end{abstract}

\section{Keywords}

adrenalectomy; DOCA; gastric distension; gastric emptying; salt appetite

\begin{abstract}
Adrenalectomized (adrex) rats adaptively compensate for the uncontrolled loss of $\mathrm{Na}^{+}$in urine due to the absence of aldosterone by consuming sufficient $\mathrm{NaCl}$ solution to maintain $\mathrm{Na}^{+}$ balance (12). When adrex rats are deprived of dietary $\mathrm{NaCl}$ and become $\mathrm{Na}^{+}$-deficient, they drink a large bout of saline when it becomes available again but stop before their physiological need for $\mathrm{Na}^{+}$has been fully satisfied (9). The issues under investigation in the present experiments are the bases for the termination of that initial drinking bout and the fate of the ingested fluid.
\end{abstract}

A pronounced salt appetite also is seen in rats given daily injections of the synthetic mineralocorticoid, deoxycorticosterone acetate (DOCA) (11), even though those animals have

\footnotetext{
Address for editorial correspondence: Dr. Edward M. Stricker, Department of Neuroscience, 360 Langley Hall, University of Pittsburgh, Pittsburgh, PA 15260, Phone: 412/624-4569, Fax: 412/624-9198, e-mail: stricker@bns.pitt.edu.

Publisher's Disclaimer: This is a PDF file of an unedited manuscript that has been accepted for publication. As a service to our customers we are providing this early version of the manuscript. The manuscript will undergo copyediting, typesetting, and review of the resulting proof before it is published in its final citable form. Please note that during the production process errors may be discovered which could affect the content, and all legal disclaimers that apply to the journal pertain.
} 
positive $\mathrm{Na}^{+}$and water balances due to the steroid-induced urinary $\mathrm{Na}^{+}$retention and the secondary renal conservation of water. This treatment presumably mimics the marked salt appetite and high blood levels of aldosterone that are seen when intact rats are deprived of dietary $\mathrm{Na}^{+}(22)$. Recent experiments have found that DOCA-treated rats drank different volumes of $0.15 \mathrm{M}-0.50 \mathrm{M} \mathrm{NaCl}$ solution depending on its concentration, with less consumed the more concentrated the fluid was (16). These and other results suggested that saline-drinking bouts are terminated by early inhibitory signals associated with increases in the osmolality of fluid emptied from the stomach (as might be detected by visceral osmoreceptors) and/or in the volume of fluid contained in the stomach and small intestine (as might be detected by stretch receptors on those organs) $(16,20)$. The present experiments examined the generality of those findings by determining whether presystemic signals also inhibit $\mathrm{NaCl}$ consumption by $\mathrm{Na}^{+}-$ deprived adrex rats.

The recent studies of DOCA-treated rats (16) also reported that gastric emptying (in ml) diminished as the concentration of ingested $\mathrm{NaCl}$ solution increased, so that the delivery of $\mathrm{Na}^{+}$(in meq) to the small intestine was stable. The present experiments sought to determine whether gastric emptying of $\mathrm{Na}^{+}$in adrex rats is similarly modulated according to the concentration of the ingested $\mathrm{NaCl}$ solution or whether it is instead modulated according to bodily $\mathrm{Na}^{+}$need, which differs markedly in the two models of salt appetite.

\section{METHODS}

\section{Animals}

Adult male Sprague-Dawley rats (Harlan Laboratories) weighing 300-425 g on the day of the terminal experiments were housed singly in wire-mesh cages in the Department of Neuroscience at the University of Pittsburgh or in plastic cages in the Biomedical Research Facility at Florida State University. The colony rooms were maintained at constant temperature $\left(22-23^{\circ} \mathrm{C}\right)$ and with a fixed light-dark cycle (lights on from 7 a.m. to 7 p.m.). All rats were given $>1$ wk of ad libitum access to pelleted laboratory chow (5001, Purina) and tap water before the surgical procedure.

\section{Experimental protocols}

Experimental protocols were reviewed by and received approval from the Institutional Animal Care and Use Committees of Florida State University (Experiment 1) and the University of Pittsburgh (Experiments 2A and 2B).

Rats were anesthetized with halothane and their adrenal glands were extirpated. Immediately after surgery they were treated with ketoprophen $(2 \mathrm{mg} / \mathrm{kg}$ s.c., for 5 days $)$ and an antibiotic $(30,000 \mathrm{U}$ of penicillin G, i.m.). Adrenalectomy was confirmed by the absence of adrenal gland tissue during post-mortem observation. In addition, all adrex rats consumed $>15 \mathrm{ml} /$ day of 0.30 $\mathrm{M} \mathrm{NaCl}$ whereas before surgery they had ingested only $0-3 \mathrm{ml} /$ day.

In preliminary experiments, separate groups of adrex rats were maintained for several days on chow, water, and either $0.05 \mathrm{M}, 0.15 \mathrm{M}$, or $0.30 \mathrm{M} \mathrm{NaCl}$. They were then deprived of saline overnight and allowed to drink water and one of the $\mathrm{NaCl}$ solutions the next morning for 60 $\min (n=11,11,7$, respectively), with food removed from the cages; intakes were recorded after $5,10,15,30$, and $60 \mathrm{~min}$. None of these animals consumed water during the test. In contrast, each rat drank saline at the same rapid rate at first $(\sim 1.7 \mathrm{ml} / \mathrm{min})$ regardless of which $\mathrm{NaCl}$ solution was available, though ingestion slowed after 8-12 min. However, whereas adrex rats continued to drink $0.05 \mathrm{M}$ and $0.15 \mathrm{M} \mathrm{NaCl}$ steadily throughout the test, they drank little $0.30 \mathrm{M} \mathrm{NaCl}$ after the first $15 \mathrm{~min}(21.6 \pm 1.9 \mathrm{ml}, 26.4 \pm 2.5 \mathrm{ml}, 15.1 \pm 1.3 \mathrm{ml}$, respectively, in $60 \mathrm{~min}$; both $P \mathrm{~s}<0.01$ in comparison to intake of $0.30 \mathrm{M} \mathrm{NaCl}$ ). Based on these findings, 
in the present experiments we focused our attention on the initial bout of saline drinking by adrex rats after overnight deprivation of $\mathrm{NaCl}$ solution. Because these observations resembled those reported previously when adrex rats were given $0.5 \mathrm{M} \mathrm{NaCl}$ to drink after $24 \mathrm{~h}$ of deprivation (9), we also included more concentrated $\mathrm{NaCl}$ solutions in this study.

The present study was deliberately designed to resemble recent investigations of rats given either $0.10 \mathrm{M}, 0.15 \mathrm{M}, 0.20 \mathrm{M}, 0.25 \mathrm{M}, 0.30 \mathrm{M}, 0.40 \mathrm{M}$, or $0.50 \mathrm{M} \mathrm{NaCl}$ to drink when salt appetite was stimulated by daily DOCA treatments (16). In order to evaluate the same issues but in a less comprehensive approach, we used $0.05 \mathrm{M} \mathrm{NaCl}$ as the hypotonic solution and only two or three hypertonic $\mathrm{NaCl}$ solutions in the following experiments.

The goal of experiment 1 was to obtain detailed information about the effects of adrenalectomy on the intakes of $0.05 \mathrm{M}, 0.15 \mathrm{M}, 0.20 \mathrm{M}, 0.30 \mathrm{M}$, and $0.40 \mathrm{M} \mathrm{NaCl}$ solutions during the initial drinking bout in order to develop criteria for the termination of a bout. Eight rats were given ad libitum access to Purina chow powder, water, and $0.30 \mathrm{M} \mathrm{NaCl}$ solution for $1 \mathrm{wk}$ in order to accustom them to the special cages in which the behavioral measurements were made (14). A 4 x 4-cm opening on the front of these cages accommodated a jar containing powdered food. The fluid bottles were supported by a rack on the back of the cage. The drinking spouts were recessed $\sim 0.5 \mathrm{~cm}$ from the cage, and the rat had access to the drinking fluid by licking through a slot in the cage wall. Licks on each drinking spout activated a contact circuit and were transmitted to a microprocessor and recorded in consecutive 6-sec time bins throughout the 1h sessions.

After an initial period of acclimation, two changes in maintenance were instituted and the experiment was begun. First, $0.15 \mathrm{M} \mathrm{NaCl}$ became available instead of $0.30 \mathrm{M} \mathrm{NaCl}$. Second, adrex rats were given access to saline only from 9 a.m. to 5 p.m., and to food only from 5 p.m. to 9 a.m.; access to water remained continuous. Prior to each daily session, the food was removed and fresh drinking fluids were provided. Four days later, on Days $5-8,0.20 \mathrm{M} \mathrm{NaCl}$ was given instead of $0.15 \mathrm{M} \mathrm{NaCl}$. Over the next 9 days a different $\mathrm{NaCl}$ solution was available. Specifically, each rat was given $0.30 \mathrm{M} \mathrm{NaCl}$ on Days 9-12, $0.40 \mathrm{M} \mathrm{NaCl}$ on Days 13-16, and $0.05 \mathrm{M} \mathrm{NaCl}$ on Day 17 .

At 5 p.m. each day, saline was removed and food was returned to the cages where it remained until 9 a.m. on the following morning. The volumes of saline consumed during the initial bout were obtained, as described previously (16), and our analyses focused on the pauses between drinks. Because cumulative intakes were obtained every $6 \mathrm{sec}$, the same intake reading in two successive 6-sec bins indicated an absence of drinking for $0.2 \mathrm{~min}$. Our goal was to determine the total number of such bins that occurred before the rats stopped drinking saline in the initial bout, so we could use that number to anticipate the end of an initial drinking bout by other adrex rats in these experiments. The analyses were limited to the intakes by the 8 adrex rats during the first 15 min of the sessions on the last day of exposure to each fluid; that is, on Days $4,8,12,16$, and 17. (Note that the daily intakes of each of the first four $\mathrm{NaCl}$ solutions in this sequence differed by $<10 \%$ during the days in which it was available.)

The goal of experiment $2 A$ was to determine the fate of saline ingested by adrex rats in an initial drinking bout after overnight deprivation of $\mathrm{NaCl}$ solution. Adrex rats were given daily access to $0.15 \mathrm{M}(n=16), 0.30 \mathrm{M}(n=14)$, or $0.50 \mathrm{M} \mathrm{NaCl}(n=5)$ from 11 a.m. to $5 \mathrm{p}$.m. in standard cages. Additional adrex rats $(n=9)$ were given daily access to $0.05 \mathrm{M} \mathrm{NaCl}$ from 11 a.m. to noon and then, after a 30-min delay, $0.30 \mathrm{M} \mathrm{NaCl}$ was available for $5 \mathrm{~h}$; this unusual schedule was used to give rats experience with $0.05 \mathrm{M} \mathrm{NaCl}$ solution while insuring that the animals consumed at least $4.5 \mathrm{meq} \mathrm{Na}{ }^{+}$daily (i.e., the amount of $\mathrm{Na}^{+}$contained in $15 \mathrm{ml}$ of $0.30 \mathrm{M}$ $\mathrm{NaCl})$. After 7-10 days of training to these schedules, rats were deprived of $\mathrm{NaCl}$ solution overnight ( $18 \mathrm{~h}$ ) and then given access to saline and water for 0-15 min. A few drops of green 
food dye (McCormick \& Co., Hunt Valley, $\mathrm{MO}$ ) were added to the $\mathrm{NaCl}$ solutions, which allowed us to track the ingested fluid within the gastrointestinal tract. Drinking fluids were presented in graduated burettes, and saline and water intakes were recorded $( \pm 0.1 \mathrm{ml})$ at the end of the experiment. Some rats $(n=9,8,3,5$, respectively) were interrupted from drinking by the experimenter (after $<5 \mathrm{~min}$ of drinking) in order to provide information about the gastrointestinal distribution of the ingested fluid before the end of the bout. The other rats $(n$ $=7,6,2,4$, respectively) were killed once they accrued $3 \min (0.50 \mathrm{M} \mathrm{NaCl})$ or $2 \min$ (all other $\mathrm{NaCl}$ solutions) of non-drinking activity, which defined the end of the first bout (see Results). Note that adrex rats drank much less $0.50 \mathrm{M} \mathrm{NaCl}$ than the other solutions in the initial bout (see Results), so there was less need to interrupt their drinking in order to determine the fate of ingested fluid after relatively small volumes were consumed.

All rats were decapitated within $10 \mathrm{~s}$ after the test ended. Trunk blood was collected in chilled heparinized tubes and the stomachs and segments of small intestine that contained dye were removed for analysis (see below). We assumed from the absence of green dye that a measurable amount of residual ingested fluid was not present in the rat's mouth and esophagus.

The goal of experiment $2 B$ was to determine the effects of an initial saline drinking bout on gastric and small intestinal fluid volumes, and on systemic plasma $\mathrm{Na}^{+}$concentration $(\mathrm{pNa})$, at various times after the bout, in order to gain insight into the mechanisms by which fluid ingested in the first bout influenced subsequent saline intake. Adrex rats were treated as in experiment $2 A$ but the bottles containing $0.05 \mathrm{M}, 0.15 \mathrm{M}$, or $0.30 \mathrm{M} \mathrm{NaCl}$ solution were removed after the initial drinking bout $(n=3,9,9$, respectively) and the rats were sacrificed 12-60 min after the start of the drinking test. Food and water also were absent during this period.

\section{Analysis of Tissues}

After decapitation, trunk blood was collected in chilled heparinized collection tubes (143 USP sodium heparin; Becton Dickinson, Franklin Lakes, NJ), which were placed in ice until they were centrifuged $\left(10,000 \times g\right.$ for $15 \mathrm{~min}$ at $\left.4^{\circ} \mathrm{C}\right)$. The plasma supernatant was collected and pNa was analyzed later using a sodium-sensitive electrode (Beckman Coulter, Synchron ELISE model 4410 , Brea, CA) while plasma protein concentration was measured $( \pm 0.1 \mathrm{~g} / \mathrm{dl})$ using a refractometer. Note that trunk blood obtained after decapitation is inevitably contaminated by intracellular fluid, and the reported pNa values are undoubtedly 2 or $3 \mathrm{mM}$ lower than actual blood values. This error was assumed to be constant across animals and therefore inconsequential when comparing $\mathrm{pNa}$ values in different groups.

The visceral organs were exposed by a midline incision on the abdomen. Hemostats were clamped at the junction of the pylorus and small intestine, the junction of the esophagus and stomach, and at the farthest point in which the green dye had traveled into the small intestine, in that order. (The third hemostat was clamped at the junction of the small intestine and cecum on the two occasions when green dye traveled into the cecum.) Subsequently, the stomach and the portion of small intestine containing dyed fluid, stripped of adhering blood vessels and connective tissues, were removed and placed into separate beakers, which were covered with Parafilm. The stomach was opened and gastric contents were removed and weighed. The length of the small intestinal segment removed was measured $( \pm 1 \mathrm{~cm})$ and weighed $( \pm 1 \mathrm{mg})$. The stomach contents and intestinal segment were desiccated until constant weight (1-2 days at 60 $\left.{ }^{\circ} \mathrm{C}\right)$.

To summarize, our goal was to analyze in each of 44 adrex rats in experiment $2 A$ and 21 rats in experiment $2 B$ all blood samples for plasma concentrations of $\mathrm{Na}^{+}$and protein, gastric chyme and small intestine (separately) for dry matter and water, and intestinal distance traversed by 
the ingested fluid. These analyses sum to a total of 455 individual measurements, of which 18 (4\%) were lost due to procedural errors.

\section{Calculations}

In order to distinguish between the ingested fluid and gastric fluid that was present before testing, we corrected for fluid associated with gastric chyme. This volume was calculated using other adrex rats $(n=7)$ that were trained with $0.30 \mathrm{M} \mathrm{NaCl}$ using a protocol similar to that described above. Rats were deprived of saline overnight and decapitated at 11 a.m. the following morning without having been tested. Trunk blood, stomach, and small intestine were collected from each animal and treated as described above. A scatter plot was constructed expressing stomach liquids of individual animals (in ml, on the $y$-axis) as a function of stomach solids (in $\mathrm{g}$, on the $x$-axis). The resulting trendline, $y=1.5831 x+0.6867(r=0.97, P<0.001)$, was used to correct for the volume of fluid associated with gastric solids in each rat tested. These corrections assume that the amount of food present in the stomach, as well as fluid associated with food, remained constant throughout the testing period.

Another correction was made in order to discriminate between orogastric secretions and ingested fluid. Briefly, in previous studies $(8,16)$ DOCA-treated rats and water-deprived rats were fitted with gastric fistulae and adapted to cages that allowed drainage and collection of gastric fluid. On average, $12.6 \%$ more fluid drained from the rats' stomachs than was consumed. Thus, we estimated the volume of orogastric secretions as $12.6 \%$ of the volume of fluid consumed by adrex rats.

Another correction was made to distinguish between fluid associated with the small intestinal lining and fluid within the intestinal lumen. The entire length of small intestine was collected from 5 of the 7 control adrex rats deprived of $\mathrm{NaCl}$ solution overnight but not allowed to drink, whereas only a segment of small intestine $(32.5$ or $47.5 \mathrm{~cm})$ was collected from the other two rats. A scatter plot was constructed expressing the total small intestinal volume of individual animals (in $\mathrm{ml}$, on the $y$-axis) as a function of intestinal segment length (in $\mathrm{cm}$, on the $x$-axis). The associated trendline, $y=0.075 x-0.0869(r=0.99, P<0.001)$, was used to correct for fluid associated with intestinal tissues per $\mathrm{cm}$. This equation is similar to others that were obtained previously $(16,21)$. The weight of the dry lining of small intestine was considered to be negligible. The value calculated from the trendline was multiplied by the length of small intestinal segment collected from each animal tested, and that product was subtracted from the total water volume of the small intestinal segment. The resulting value was considered to be the volume of fluid in the intestinal lumen.

In order to calculate the percent of ingested fluid that emptied from the stomach, the fluid remaining in the stomach (corrected for fluid associated with gastric chyme) was subtracted from the volume of intake (corrected for orogastric secretions) and then divided by the volume of intake (corrected for orogastric secretions) and multiplied by 100. Gastrointestinal (GI) fill was computed as the sum of the volume of fluid that remained in the stomach (corrected for the fluid associated with gastric chyme) and the volume of fluid in the intestinal lumen. Mean intestinal distension was calculated by dividing the intestinal lumen volume (in $\mathrm{ml}$ ) by the intestinal length that contained dyed liquid (in $\mathrm{cm}$ ).

\section{Statistical Analyses}

All data are presented in scatterplots or as means \pm SE. Statistical reliability of observed differences was determined using $t$-tests or ANOVA with Scheffe comparison. Regression equations were calculated by the method of least squares, and significance was determined using Pearson's correlation coefficients or curvilinear methods when the data were better fit to logarithmic or exponential functions. Differences in the slopes of lines were determined by 
converting individual data points into ratios of the two variables (i.e., $y$-value/ $x$-value) and then comparing the groups by ANOVA. $P<0.05$ was considered to be statistically significant.

\section{RESULTS \\ Experiment 1}

After overnight deprivation of $\mathrm{NaCl}$ solution, the adrex rats drank with few pauses at first but then they consumed fluid with increasingly more frequent and longer pauses before stopping after 5-10 min. When the number of 6-sec pauses per minute was plotted as a function of time, a similar linear trendline was found for the first $9 \mathrm{~min}$ of the initial bouts of $0.05 \mathrm{M}, 0.15 \mathrm{M}$, $0.20 \mathrm{M}$, or $0.30 \mathrm{M} \mathrm{NaCl}$. Shown in Fig. 1 is the line for group means. There were 0-2 pauses in each of the first $4 \mathrm{~min}$ of the bout, 4-5 pauses/min in the next $3 \mathrm{~min}, 6-7$ pauses $/ \mathrm{min}$ in the next $2 \mathrm{~min}$, and 8-10 pauses/min thereafter. In other words, about $2 \mathrm{~min}$ of total pause time was reached after 7-9 min of the bout, after which rats drank $<10 \%$ of each minute. An extra 1.7 pauses/min were observed when adrex rats drank $0.40 \mathrm{M} \mathrm{NaCl}$ instead of the more dilute solutions, and an extra minute of pause time was accrued when they stopped drinking after 6$8 \mathrm{~min}$. No water was consumed by any rat during the saline bout.

\section{Experiment 2A}

All adrex rats began to drink saline soon after the drinking tube was returned to the cage. As shown in Fig. 2A, they consumed $0.05 \mathrm{M}, 0.15 \mathrm{M}$, or $0.30 \mathrm{M} \mathrm{NaCl}$ at a steady rate $(1.65 \pm 0.04$ $\mathrm{ml} / \mathrm{min})$ that was faster than the rate at which they drank $0.50 \mathrm{M} \mathrm{NaCl}(1.06 \pm 0.07 \mathrm{ml} / \mathrm{min}$; $P<0.001)$. They did not drink water during or immediately after this initial drinking bout. For each rat, non-drinking activity was intermittent and usually consisted of grooming or exploring the cage. When these data were analyzed in terms of meq $\mathrm{Na}^{+} / \mathrm{min}$ instead of $\mathrm{ml} / \mathrm{min}$, adrex rats were found to drink $0.30 \mathrm{M}$ and $0.50 \mathrm{M} \mathrm{NaCl}$ at a similar rate (Fig. 2B). That rate $(0.51 \pm$ $0.02 \mathrm{meq} \mathrm{Na} / \mathrm{min}$ ) was twice as fast as the rate at which adrex rats consumed $0.15 \mathrm{M} \mathrm{NaCl}$ $\left(0.25 \pm 0.01 \mathrm{meq} \mathrm{Na}{ }^{+} / \mathrm{min} ; P<0.001\right)$, which was three times as fast as the rate at which they drank $0.05 \mathrm{M} \mathrm{NaCl}(0.08 \pm 0.01 \mathrm{meq} \mathrm{Na} / \mathrm{min} ; P<0.001)$.

The amount of fluid emptied from the stomach increased in proportion to the amount of time that rats spent drinking, but it varied according to concentration of $\mathrm{NaCl}$ solution ingested. Specifically, $0.05 \mathrm{M}$ and $0.15 \mathrm{M} \mathrm{NaCl}$ emptied at a similar rate $(1.06 \pm 0.08 \mathrm{ml} / \mathrm{min})$ that was much faster than the rate at which $0.30 \mathrm{M}$ and $0.50 \mathrm{M} \mathrm{NaCl}$ emptied $(0.33 \pm 0.04 \mathrm{ml} / \mathrm{min}, P$ $<0.001$; Fig. 3A). However, when these data were plotted as meq $\mathrm{Na}^{+}$instead of $\mathrm{ml}$, a different picture was seen. Ingested $0.15 \mathrm{M}, 0.30 \mathrm{M}$, or $0.50 \mathrm{M} \mathrm{NaCl}$ emptied at a similar rate $(0.13 \pm$ $0.01 \mathrm{meq} \mathrm{Na} / \mathrm{min}$ ), which was significantly faster than the rate at which $0.05 \mathrm{M} \mathrm{NaCl}$ emptied $\left(0.05 \pm 0.01\right.$ meq $\mathrm{Na}^{+} / \mathrm{min}, P<0.001 ;$ Fig. 3B $)$.

The $\mathrm{NaCl}$ solutions that emptied from the stomach traveled a similar distance into the small intestine for a given intestinal volume, regardless of their concentration (Fig. 4). The best-fit trendline was logarithmic. Thus, the initial $0.5 \mathrm{ml}$ of emptied fluid went $30-55 \mathrm{~cm}$ into the small intestine, but the traversed distance increased less rapidly as more fluid accumulated in the small intestine. Conversely, mean intestinal distension increased linearly as fluid volume in the intestinal lumen increased, regardless of which $\mathrm{NaCl}$ solution was consumed (Fig. 5).

The sum of ingested fluid in the stomach and small intestine ("GI fill") increased in proportion to the volume of ingested saline, but two regression lines were obtained depending on $\mathrm{NaCl}$ concentration. As shown in Fig. 6, GI fill was approximately equal to the volume of ingested fluid when rats consumed $0.30 \mathrm{M}$ or $0.50 \mathrm{M} \mathrm{NaCl}$, whereas it was $\sim 65 \%$ of the intake volume when rats drank $0.05 \mathrm{M}$ or $0.15 \mathrm{M} \mathrm{NaCl}(P<0.001)$. 
Table 1 presents systemic $\mathrm{pNa}$ and plasma protein concentrations of adrex rats before and immediately after the drinking test, and provides values from intact control rats for purposes of comparison. All adrex rats were hyponatremic (all $P \mathrm{~s}<0.001$ ), and their $\mathrm{pNa}$ did not change significantly while they ingested saline. The plasma protein concentrations of adrex rats not given access to saline were slightly elevated, but fluid consumption lowered values towards those of untreated control rats except when $0.50 \mathrm{M} \mathrm{NaCl}$ was ingested.

\section{Experiment 2B}

Adrex rats allowed to drink an initial bout of either $0.05 \mathrm{M}$ or $0.15 \mathrm{M} \mathrm{NaCl}$ and then killed at various times subsequently showed a progressive decrease in gastric fill and GI fill with time. Specifically, rats drinking $0.05 \mathrm{M} \mathrm{NaCl}$ emptied $\sim 80 \%$ of the ingested fluid from the stomach by $15 \mathrm{~min}$ after the start of the drinking test and $\sim 100 \%$ of the fluid by $30 \mathrm{~min}$, whereas rats drinking $0.15 \mathrm{M} \mathrm{NaCl}$ emptied at a slightly slower rate $(\sim 60 \%, \sim 80 \%$, by 15 and $30 \mathrm{~min}$, respectively; not shown). As displayed in Fig. 7, GI fill decreased similarly in these two groups, and only 30-60\% of ingested fluid remained in the stomach and small intestine by $40 \mathrm{~min}$. These rapid rates of gastric emptying and intestinal absorption were in marked contrast with those seen when rats drank $0.30 \mathrm{M} \mathrm{NaCl}$. Although $\sim 70 \%$ of the ingested fluid was emptied from the stomach during the 60-min period (not shown), nonetheless there was little decrease in GI fill during this period (Fig. 7).

Systemic $\mathrm{pNa}$ were not significantly affected when adrex rats drank $0.05 \mathrm{M} \mathrm{NaCl}$ or $0.15 \mathrm{M}$ $\mathrm{NaCl}$ in an initial bout and were sacrificed 20-60 min after the start of the drinking test (138.5 \pm 1.6 meq Na${ }^{+} / l, 137.2 \pm 0.9$ meq Na${ }^{+} / l$, respectively; see Table 1 for $\mathrm{pNa}$ values from adrex rats not given saline to drink). In contrast, systemic pNa were significantly elevated when 0.30 $\mathrm{M} \mathrm{NaCl}$ was consumed under these circumstances $\left(142.9 \pm 1.1 \mathrm{meq} \mathrm{Na}{ }^{+} / 1 ; P<0.01\right)$. The plasma protein concentrations of these rats $(6.1 \pm 0.1,6.1 \pm 0.2,6.5 \pm 0.1 \mathrm{~g} / \mathrm{dl}$, respectively) were not significantly different from those of rats drinking the same solutions but killed soon after the initial bout (see Table 1).

\section{DISCUSSION}

In the present experiments, adrex rats were given one of several $\mathrm{NaCl}$ solutions to drink after an overnight period of saline deprivation. As expected $(9,13,16)$, they drank these solutions avidly but stopped before their physiological need for $\mathrm{Na}^{+}$had been satisfied. Four striking results were observed. First, intake of $\mathrm{NaCl}$ solution (in $\mathrm{ml} / \mathrm{min}$ ) was maximal except when the animals consumed $0.50 \mathrm{M} \mathrm{NaCl}$. Second, intake of the hypertonic $\mathrm{NaCl}$ solutions (in meq/ min) appeared to be regulated. Third, saline intake appeared to be inhibited both when the concentration of fluid that emptied from the stomach was very elevated (i.e., $0.50 \mathrm{M} \mathrm{NaCl}$ ) and when the stomach and small intestine were distended. And fourth, gastric emptying of ingested $\mathrm{NaCl}$ solution (in $\mathrm{ml} / \mathrm{min}$ ) either was very fast (hypotonic or isotonic solution) or relatively slow (hypertonic solution), yet the rate at which $\mathrm{Na}^{+}$emptied into the small intestine (in $\mathrm{meq} / \mathrm{min}$ ) appeared to be regulated except when the animals consumed a very dilute solution (i.e., $0.05 \mathrm{M} \mathrm{NaCl}$ ). Thus, although adrex rats lose $\mathrm{Na}^{+}$in urine uncontrollably, they retain the capacity to regulate the rate (in meq/min) at which $\mathrm{Na}^{+}$is consumed and delivered to the stomach and small intestine.

Collectively, these results closely resemble those from similar studies of $\mathrm{NaCl}$ intake and gastric emptying in rats when salt appetite was induced by daily treatment with DOCA (16). The DOCA-treated rats drank saline at rates of $1.8 \mathrm{ml} / \mathrm{min}$ (of $0.10 \mathrm{M}, 0.15 \mathrm{M}, 0.20 \mathrm{M}, 0.25$ $\mathrm{M}$, and $0.30 \mathrm{M} \mathrm{NaCl}$ ) and $0.45 \mathrm{meq} \mathrm{Na}^{+} / \mathrm{min}$ (of $0.20 \mathrm{M}, 0.25 \mathrm{M}, 0.30 \mathrm{M}, 0.40 \mathrm{M}$, and 0.50 $\mathrm{M} \mathrm{NaCl}$ ), and emptied $\mathrm{Na}^{+}$from the stomach at the rate of $0.18 \mathrm{meq} / \mathrm{min}$ (of $0.10 \mathrm{M}-0.50 \mathrm{M}$ $\mathrm{NaCl}$ ), all of which values were similar to those of adrex rats in the present study. Also similar in DOCA-treated rats were the relations between intestinal distance and intestinal volume $(y$ 
$=24.66 \ln (x)+42.22)$ and between mean intestinal distension and intestinal volume $(0.008$ $\mathrm{ml} / \mathrm{cm}$ per $\mathrm{ml}$ ), and the two trendlines relating GI fill to fluid intake, one for concentrated saline $(0.99 \mathrm{ml}$ per $\mathrm{ml})$ and one for dilute and isotonic saline $(0.84 \mathrm{ml}$ per $\mathrm{ml})$. Thus, there was no substantial difference between the two groups in the way that ingested $\mathrm{NaCl}$ was processed in the gastrointestinal tract even though one model of salt appetite involved significant bodily $\mathrm{Na}^{+}$deficits while the other was associated with positive $\mathrm{Na}^{+}$balance.

These findings suggest that gastric emptying of $\mathrm{Na}^{+}$in rats is modulated according to the concentration of the ingested $\mathrm{NaCl}$ solution rather than bodily $\mathrm{Na}^{+}$need. Consistent with that hypothesis are additional findings (M.R. Bykowski, unpublished B.Phil. thesis, 2006) that similar relations between intake and gastric emptying were observed whether adrex rats drank $0.30 \mathrm{M} \mathrm{NaCl}$ after $16 \mathrm{~h}$ or $40 \mathrm{~h}$ of saline deprivation. Further support is provided by studies of saline ingestion and gastric emptying when thirst was induced in rats by overnight water deprivation (8). Specifically, the rate of ingestion $(1.7 \mathrm{ml} / \mathrm{min}$ when dehydrated rats drank 0.05 $\mathrm{M}, 0.10 \mathrm{M}, 0.15 \mathrm{M}$, or $0.20 \mathrm{M} \mathrm{NaCl}$ ) was similar to that observed when adrex rats drank those fluids, as were the relations between intestinal distance and intestinal volume $(y=21.75 \ln (x)$ $+40.95)$ and between mean intestinal distension and intestinal volume $(0.010 \mathrm{ml} / \mathrm{cm} \mathrm{per} \mathrm{ml})$. In addition, similar trendlines were seen relating GI fill and intake, one for $0.20 \mathrm{M} \mathrm{NaCl}(1.05$ $\mathrm{ml}$ per $\mathrm{ml}$ ) and one for water and the more dilute $\mathrm{NaCl}$ solutions $(0.77 \mathrm{ml}$ per $\mathrm{ml})$. In short, the rates of ingestion and digestion of these saline solutions were consistent across models of salt appetite and thirst in rats, and they did not appear to be influenced either by the specific motivation of the rat or its needs.

Because the present results resembled those reported recently $(8,13,16)$, a full discussion of the findings and their implications will not be repeated. However, a few observations were unique to the adrex rat and therefore warrant additional comments.

Previous studies suggest that after overnight deprivation of $\mathrm{NaCl}$ solution, the cumulative $\mathrm{Na}^{+}$deficits of adrex rats are 1.5-2.0 meq (9). In order to obtain that amount given their intake rates (Fig. 2B), the rats had to drink $0.05 \mathrm{M} \mathrm{NaCl}$ for $15-20 \mathrm{~min}, 0.15 \mathrm{M} \mathrm{NaCl}$ for 5-7 min, and $0.30 \mathrm{M}$ and $0.50 \mathrm{M} \mathrm{NaCl}$ for 3-4 min. In fact, in the present experiments they drank the two concentrated solutions for slightly longer than the required times and the dilute solution for much less time, but in each case they stopped drinking while most of the consumed saline was still in the stomach and small intestine and before there were significant changes in systemic $\mathrm{pNa}$ and plasma protein concentration.

Note that we depended on analysis of the detailed drinking records in experiment 1 to determine when the initial bout ended. It revealed that pauses in drinking became longer and more frequent until ingestion stopped for $>5 \mathrm{~min}$. When drinking stopped the cumulative pause time in the bout amounted to $\sim 2 \mathrm{~min}$ when rats drank $0.05 \mathrm{M}, 0.15 \mathrm{M}$, or $0.30 \mathrm{M} \mathrm{NaCl}$ solution, so we used those values to operationally define the end of the bout in experiment $2 \mathrm{~A}$. Similarly, the cumulative pause time amounted to $\sim 3 \mathrm{~min}$ when rats drank $0.40 \mathrm{M} \mathrm{NaCl}$, so that value defined the end of the bout when rats drank $0.50 \mathrm{M} \mathrm{NaCl}$ in experiment $2 \mathrm{~A}$. In this regard, we were guided by previous observations that DOCA-treated rats drank $0.40 \mathrm{M}$ and $0.50 \mathrm{M} \mathrm{NaCl}$ at the same rate (16).

It seems noteworthy that the rate of $\mathrm{Na}^{+}$consumption was similar $(\sim 0.5 \mathrm{meq} / \mathrm{min})$ whether adrex rats drank $0.30 \mathrm{M}$ or $0.50 \mathrm{M} \mathrm{NaCl}$, and that both groups consumed similar amounts (in meq $\mathrm{Na}^{+}$) in an initial bout. Those observations are consistent with the possibility that $\mathrm{Na}^{+}$ intake is regulated when adrex rats drink $0.30 \mathrm{M}$ or $0.50 \mathrm{M} \mathrm{NaCl}$. But why, then, didn't the rats consume the same amount of $\mathrm{Na}^{+}$when they drank $0.05 \mathrm{M}$ or $0.15 \mathrm{M} \mathrm{NaCl}$ ? We propose that they drank the less concentrated solutions at a maximally high rate (in $\mathrm{ml} / \mathrm{min}$ ) until intake was inhibited by a presystemic visceral signal related to the volume of ingested saline, as 
appears to be the case in DOCA-treated rats (16). Note that thirst and vasopressin secretion in dogs and humans are inhibited by an early volume-dependent signal generated by oropharyngeal receptors that monitor the swallowing of liquids $(6,24)$, but this control mechanism does not exist in rats $(8,19)$.

Saline ingestion by adrex rats occurred at a faster rate $(0.05 \mathrm{M}, 0.15 \mathrm{M}$, and $0.30 \mathrm{M} \mathrm{NaCl}, 1.66$ $\mathrm{ml} / \mathrm{min} ; 0.50 \mathrm{M} \mathrm{NaCl}, 1.06 \mathrm{ml} / \mathrm{min})$ than did gastric emptying during the initial bout $(0.05 \mathrm{M}$ and $0.15 \mathrm{M} \mathrm{NaCl}, 1.06 \mathrm{ml} / \mathrm{min} ; 0.30 \mathrm{M}$ and $0.50 \mathrm{M} \mathrm{NaCl}, 0.33 \mathrm{ml} / \mathrm{min}$ ). Consequently, ingested fluid accumulated in the stomach. How much fluid remained in the stomach depended in part on the concentration of saline that was consumed. Indeed, gastric emptying appeared to be modulated so that the rate at which $\mathrm{Na}^{+}$emptied from the stomach was similar whether adrex rats drank $0.15 \mathrm{M}, 0.30 \mathrm{M}$, or $0.50 \mathrm{M} \mathrm{NaCl}(0.13 \mathrm{meq} / \mathrm{min}$, Fig. 3B). That rate was much faster than the rate at which adrex rats emptied $0.05 \mathrm{M} \mathrm{NaCl}\left(0.05 \mathrm{meq} \mathrm{Na}^{+} / \mathrm{min}\right)$, presumably because the latter solution was so dilute.

All concentrations of $\mathrm{NaCl}$ solution traversed the small intestine in a similar relation to the fluid volume in the small intestine (Fig. 4). The common regression line probably results from the fluids becoming isotonic to body fluids once they emptied into the small intestine and equilibrated with the rest of body fluids (5). Mean distension of the small intestine increased linearly in proportion to the fluid volume within the intestinal lumen above an apparent threshold of $0.4 \mathrm{ml}$ (Fig. 5), a small volume which is emptied from the stomach after a few minutes of saline ingestion (Fig. 3A) and is associated with an intestinal distance of $20-30 \mathrm{~cm}$ (Fig. 4). If visceral osmo- or $\mathrm{Na}^{+}$-receptors are located in that proximal portion of the small intestine, as suggested recently $(13,20)$, then those receptors may be stimulated before intestinal stretch receptors can detect distension.

Increasing intestinal distension allows for an expanded surface area from which fluid can be absorbed into the mesenteric vasculature. Inspection of Fig. 6 suggests that the net volume of absorbed fluid (i.e., the difference between GI fill and the "no net absorption" line) increased in proportion to intake when adrex rats drank $0.05 \mathrm{M}$ or $0.15 \mathrm{M} \mathrm{NaCl}$. In contrast, adrex rats that drank $0.30 \mathrm{M}$ or $0.50 \mathrm{M} \mathrm{NaCl}$ seemed to have little or no net intestinal absorption of fluid, presumably because less fluid was emptied from the stomach and any absorption that did occur was counterbalanced by the osmotic movement of water into the intestinal lumen. Whichever $\mathrm{NaCl}$ solution was consumed, however, GI fill was highly correlated with intake. Additional work is needed to determine whether these correlations reflect causal relations.

The results of experiment $2 \mathrm{~B}$ suggest that presystemic signals may influence saline ingestion by adrex rats throughout a 60 -min test. Gastric emptying of the initial bout of ingested $0.30 \mathrm{M}$ $\mathrm{NaCl}$ was $50 \%$ by $10 \mathrm{~min}$, but stomach fill decreased only gradually thereafter while the rats were not drinking. Nonetheless, loss of $50 \%$ of the fluid volume in the stomach should have allowed additional intake if gastric distension provided the main inhibitory signal to terminate ingestion. However, combined distension of the stomach and small intestine remained high and may have provided sustained inhibition of intake. Elevated systemic pNa may have contributed an additional inhibitory signal. In contrast, gastrointestinal distension diminished rapidly after the initial bout when $0.05 \mathrm{M}$ or $0.15 \mathrm{NaCl}$ was consumed, and perhaps in consequence intake of those two fluids continued throughout the test.

Salt appetite in rats appears to result, at least in part, from a combination of increased excitation provided by blood-borne mineralocorticoids and angiotensin II $(4,15)$ and decreased inhibition from central oxytocinergic neurons (see Ref. 23 for review), with these actions integrated in the nucleus tractus solitarius (NTS) in the brain stem (7). Previous studies found that substantial increases in the intake of $0.40 \mathrm{M} \mathrm{NaCl}$ occurred in DOCA-treated rats after unmyelinated visceral afferents were destroyed by systemic administration of the neurotoxin capsaicin (2), 
which may have disrupted volume- and concentration-dependent inhibitory signals from the stomach and small intestine to the NTS and area postrema in the brain stem (10). Those neurally-mediated signals also may have been disrupted by focal lesions of the area postrema, which are known to markedly increase spontaneous ingestion of $0.50 \mathrm{M} \mathrm{NaCl}(3,18)$. Other reports have suggested the presence of visceral osmo- or $\mathrm{Na}^{+}$-receptors in rats, which can detect the presence of hypertonic $\mathrm{NaCl}$ solution in the small intestine and initiate VP secretion and thirst before systemic pOsm increases $(1,17)$. The signal from those receptors might also inhibit salt appetite and gastric emptying when adrex rats drink concentrated $\mathrm{NaCl}$ solutions.

To summarize, the control of $\mathrm{NaCl}$ solution intake by adrex rats appears to be influenced by the fluid volume in the stomach and small intestine and also by the concentration of the fluid emptied from the stomach, as was reported in DOCA-treated rats (16). Adrex rats that drank $0.05 \mathrm{M}$ or $0.15 \mathrm{M} \mathrm{NaCl}$ stopped drinking in response to a volume-related signal, perhaps gastrointestinal distension, whereas intake of $0.50 \mathrm{M} \mathrm{NaCl}$ was additionally inhibited by emptying of hypertonic fluid from the stomach, perhaps mediated by visceral osmo- or $\mathrm{Na}^{+}-$ receptors. Remarkably, adrex rats emptied $0.15 \mathrm{M}, 0.30 \mathrm{M}$, and $0.50 \mathrm{M} \mathrm{NaCl}$ from the stomach at the same rate (in meq $\mathrm{Na}^{+} / \mathrm{min}$ ). These findings suggest that adrex rats can integrate presystemic information about the volume and concentration of ingested $\mathrm{NaCl}$ solution and use that information to control gastric emptying of needed $\mathrm{Na}^{+}$. Furthermore, the same presystemic signals appear to influence their ingestion of $\mathrm{NaCl}$ solution. Future experiments must determine the physiological mechanisms that control these functions.

\section{Acknowledgements}

This research was supported in part by a grant from the U.S. National Institute of Mental Health (MH-25140). The authors are grateful for the expert technical assistance of April Protzik, and the helpful comments of Michael Bushey, Myriam Hoffmann, Reza Manesh, and Jennifer Vaughan. Portions of this work were submitted by M.R. Bykowski in partial fulfillment of the requirements for the B.Phil. degree from the Honors College at the University of Pittsburgh. Preliminary versions of this report were presented at the meeting of the Society for the Study of Ingestive Behavior held in Pittsburgh, PA in July 2005, and at the meeting of Experimental Biology held in Washington, D.C. in April 2007.

\section{References}

1. Choi-Kwon S, McCarty R, Baertschi AJ. Splanchnic control of vasopressin secretion in conscious rats. Am J Physiol 1990;259:E19-E26. [PubMed: 2142582]

2. Curtis KS, Stricker EM. Enhanced fluid intake by rats after capsaicin treatment. Am J Physiol 1997;272:R704-R709. [PubMed: 9124498]

3. Curtis KS, Verbalis JG, Stricker EM. Area postrema lesions in rats appear to disrupt rapid feedback inhibition of fluid intake. Brain Res 1996;726:31-38. [PubMed: 8836542]

4. Fluharty SJ, Epstein AN. Sodium appetite elicited by intracerebroventricular infusion of angiotensin II in the rat: II. Synergistic interaction with systemic mineralocorticoids. Behav Neurosci 1983;97:746-758. [PubMed: 6639747]

5. Follansbee R. The osmotic activity of gastrointestinal fluids after water ingestion in the rat. Am J Physiol 1945;144:355-362.

6. Geelen G, Keil LC, Kravik SE, Wade CE, Thrasher TN, Barnes PR, Pyka G, Nesvig C, Greenleaf JE. Inhibition of plasma vasopressin after drinking in dehydrated humans. Am J Physiol 1984;247:R968R971. [PubMed: 6507654]

7. Geerling JC, Engeland WC, Kawata M, Loewy AD. Aldosterone target neurons in the nucleus tractus solitarius drive sodium appetite. J Neurosci 2006;26:411-417. [PubMed: 16407537]

8. Hoffmann ML, DenBleyker M, Smith JC, Stricker EM. Inhibition of thirst when dehydrated rats drink water or saline. Am J Physiol 2006;290:R1199-R1207.

9. Jalowiec JE, Stricker EM. Sodium appetite in adrenalectomized rats following dietary sodium deprivation. J Comp Physiol Psychol 1973;83:66-77. [PubMed: 4684975] 
10. Norgren R, Smith GP. Central distribution of subdiaphragmatic vagal branches in the rat. J Comp Neurol 1988;273:207-223. [PubMed: 3417902]

11. Rice KK, Richter CP. Increased sodium chloride and water intake of normal rats treated with desoxycorticosterone acetate. Endocrinology 1943;33:106-115.

12. Richter CP. Increased salt appetite in adrenalectomized rats. Am J Physiol 1936;115:155-161.

13. Smith CA, Curtis KS, Smith JC, Stricker EM. Presystemic influences on thirst, salt appetite, and vasopressin secretion in the hypovolemic rat. Am J Physiol 2007;292:R2089-R2099.

14. Smith JC. Microstructure of the rat's intake of food; sucrose and saccharin. Neurosci Biobeh Rev 2000;24:199-212.

15. Stricker EM. Thirst and sodium appetite after colloid treatment in rats: Role of the renin-angiotensinaldosterone system. Behav Neurosci 1983;97:725-737. [PubMed: 6639745]

16. Stricker EM, Bushey MA, Hoffmann ML, McGhee M, Cason AM, Smith JC. Inhibition of NaCl appetite when DOCA-treated rats drink saline. Am J Physiol 2007;292:R652-R662.

17. Stricker EM, Callahan JB, Huang W, Sved AF. Early osmoregulatory stimulation of neurohypophyseal hormone secretion and thirst after gastric $\mathrm{NaCl}$ loads. Am J Physiol 2002;282:R1710-R1717.

18. Stricker EM, Curtis KS, Peacock K, Smith JC. Rats with area postrema lesions have lengthy eating and drinking bouts when fed ad libitum: Implications for feedback inhibition of ingestive behavior. Behav Neurosci 1997;111:624-633.

19. Stricker EM, Hoffmann ML. Inhibition of vasopressin secretion when dehydrated rats drink water. Am J Physiol 2005;289:R1238-R1243.

20. Stricker EM, Hoffmann ML. Presystemic signals in the control of thirst, salt appetite, and vasopressin secretion. Physiol Behav. 2007in press

21. Stricker EM, Hoffmann ML, Riccardi CJ, Smith JC. Increased water intake by rats maintained on high $\mathrm{NaCl}$ diet: analysis of ingestive behavior. Physiol Behav 2003;79:621-631. [PubMed: 12954403]

22. Stricker EM, Thiels E, Verbalis JG. Sodium appetite in rats after prolonged dietary sodium deprivation: A sexually dimorphic phenomenon. Am J Physiol 1991;260:R1082-R1088. [PubMed: 2058736]

23. Stricker EM, Verbalis JG. Central inhibition of salt appetite by oxytocin in rats. Reg Peptides 1996;66:83-85.

24. Thrasher TN, Nistal-Herrera JF, Keil LC, Ramsay DJ. Satiety and inhibition of vasopressin secretion after drinking in dehydrated dogs. Am J Physiol 1981;240:E394-E401. [PubMed: 7013497] 


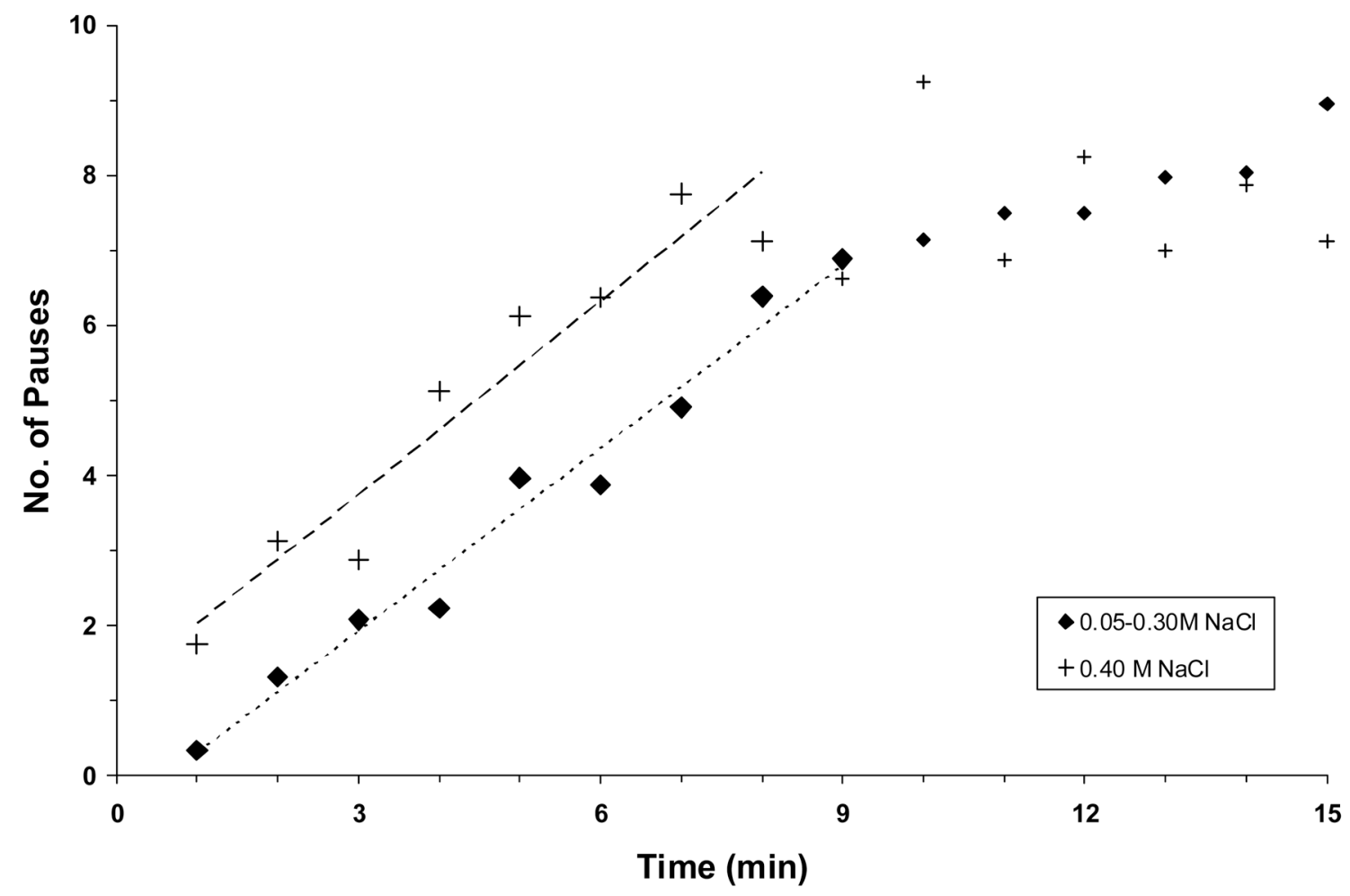

Fig. 1.

The mean number of 6-sec pauses in drinking per minute plotted as a function of time during an initial drinking bout when adrex rats $(n=8)$ ingested $0.15 \mathrm{M}, 0.20 \mathrm{M}, 0.30 \mathrm{M}$, or $0.40 \mathrm{M}$ $\mathrm{NaCl}$. Symbols represent mean data collected from animals either during (large symbols) or after the initial bout (small symbols), dashed lines represent regression lines. There were few pauses in the first minute when adrex rats consumed $0.05 \mathrm{M}-0.30 \mathrm{M} \mathrm{NaCl}$, but then they drank increasingly more slowly until they stopped. The equation of the regression line and correlation coefficient during the first 9 min of drinking are $y=0.81 x-0.51(r=0.99, P$ $<0.001)$. In contrast, there were $\sim 2$ pauses in the first minute when adrex rats consumed 0.40 $\mathrm{M} \mathrm{NaCl}$ and an increasing number of pauses subsequently. The equation of the regression line and correlation coefficient during the first $8 \mathrm{~min}$ of drinking are $y=0.86 x+1.16(r=0.96, P$ $<0.001)$. The slopes of the two trendlines are not significantly different from one another. 


\section{Figure 2A}

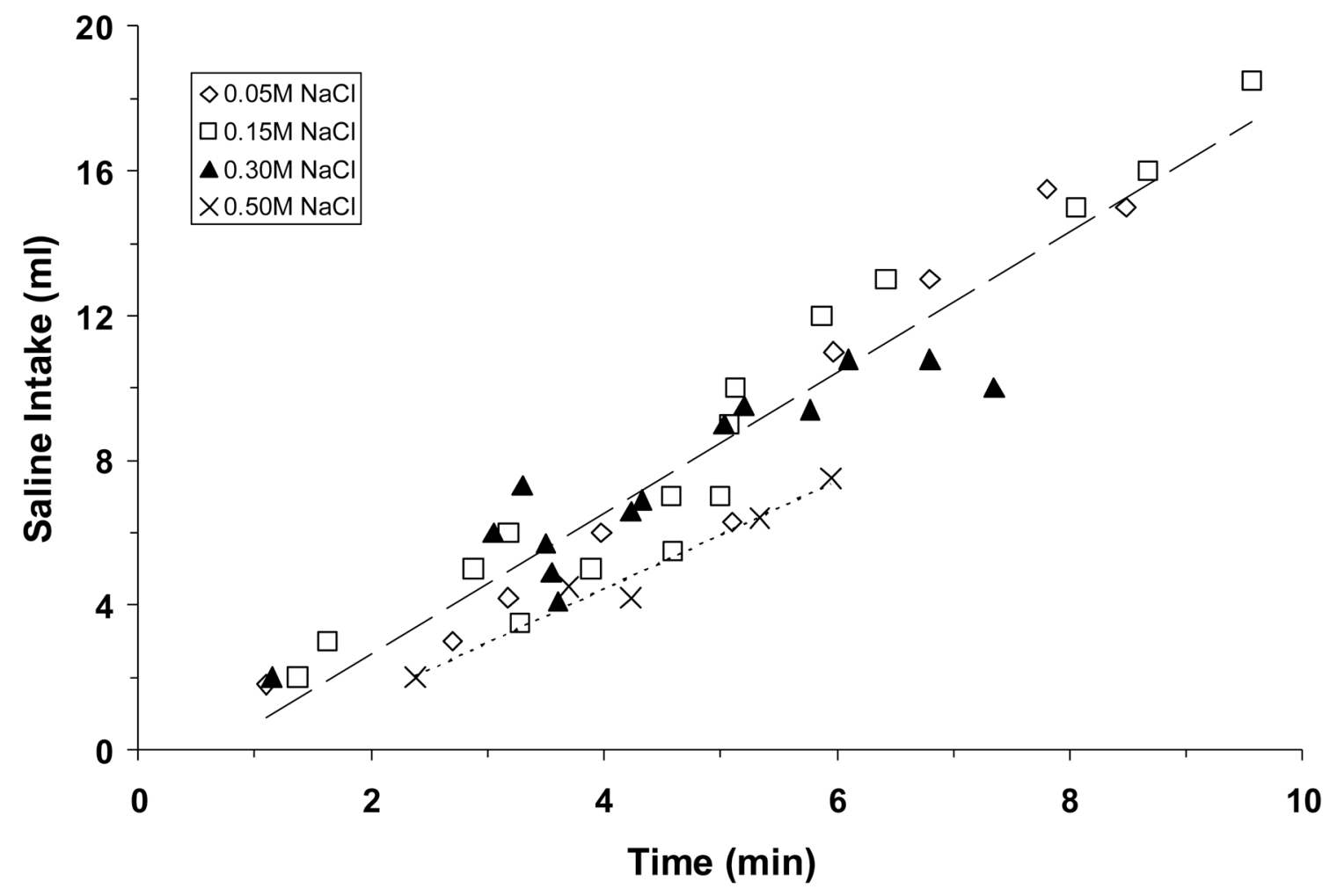


Figure 2B

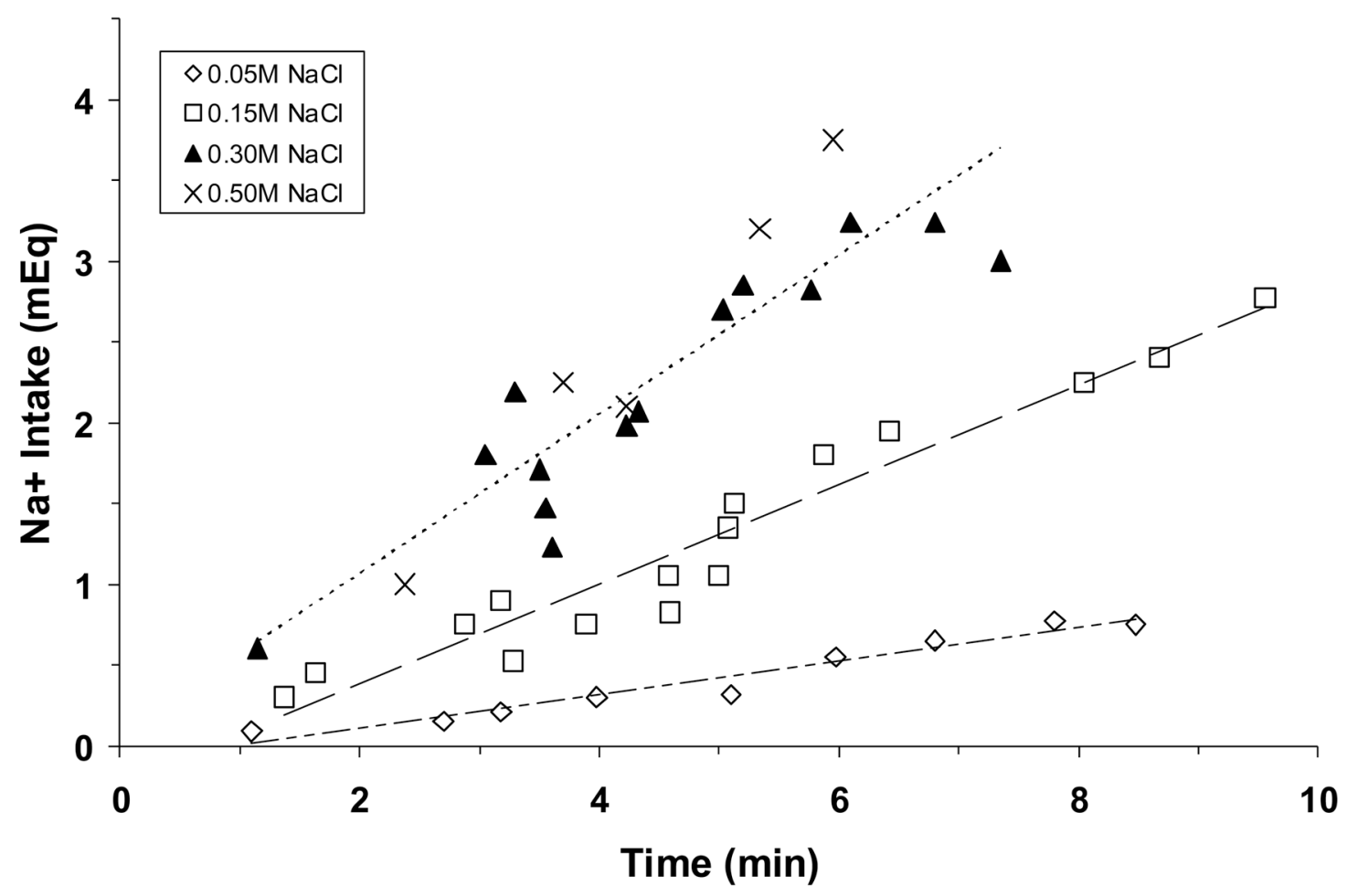

Fig. 2.

Mean intakes of $\mathrm{NaCl}$ solution by adrex rats, plotted as a function of time spent drinking. Shown are intakes in $\mathrm{ml}(\mathrm{A})$ and in meq $\mathrm{Na}^{+}(\mathrm{B})$. Symbols represents data from individual animals, dashed lines represent regression lines. Regression equations in Fig. 2A: for $0.05 \mathrm{M}$, $0.15 \mathrm{M}$, and $0.30 \mathrm{M} \mathrm{NaCl}$ (upper line), $y=1.9445 x-1.2263$; for $0.50 \mathrm{M} \mathrm{NaCl}, y=1.4904 x-$ 1.5187. Regression equations in Fig. 2B: for $0.05 \mathrm{M} \mathrm{NaCl}$ (lower line), $y=0.1038 x-0.0991$; for $0.15 \mathrm{M}$ (middle line), $y=0.3086 x-0.2380$; for $0.30 \mathrm{M}$ and $0.50 \mathrm{M} \mathrm{NaCl}$ (upper line), $y=$ $0.4924 x+0.0819$. The very high correlations between fluid intake and drinking time (Fig. 2A: $r=0.96,0.98$; Fig. 2B: $\mathrm{r}=0.97,0.97,0.90$, respectively; all $P \mathrm{~s}<0.001)$ suggest a steady rate of intake by these animals (excluding pauses). Adrex rats consumed $0.05 \mathrm{M}, 0.15 \mathrm{M}$, or 0.30 $\mathrm{M} \mathrm{NaCl}$ more rapidly in $\mathrm{ml} / \mathrm{min}$ than they consumed $0.50 \mathrm{M} \mathrm{NaCl}$, whereas they ingested 0.30 $\mathrm{M}$ and $0.50 \mathrm{M} \mathrm{NaCl}$ at the fastest rate in meq $\mathrm{Na}^{+} / \mathrm{min}$. 
Figure 3A

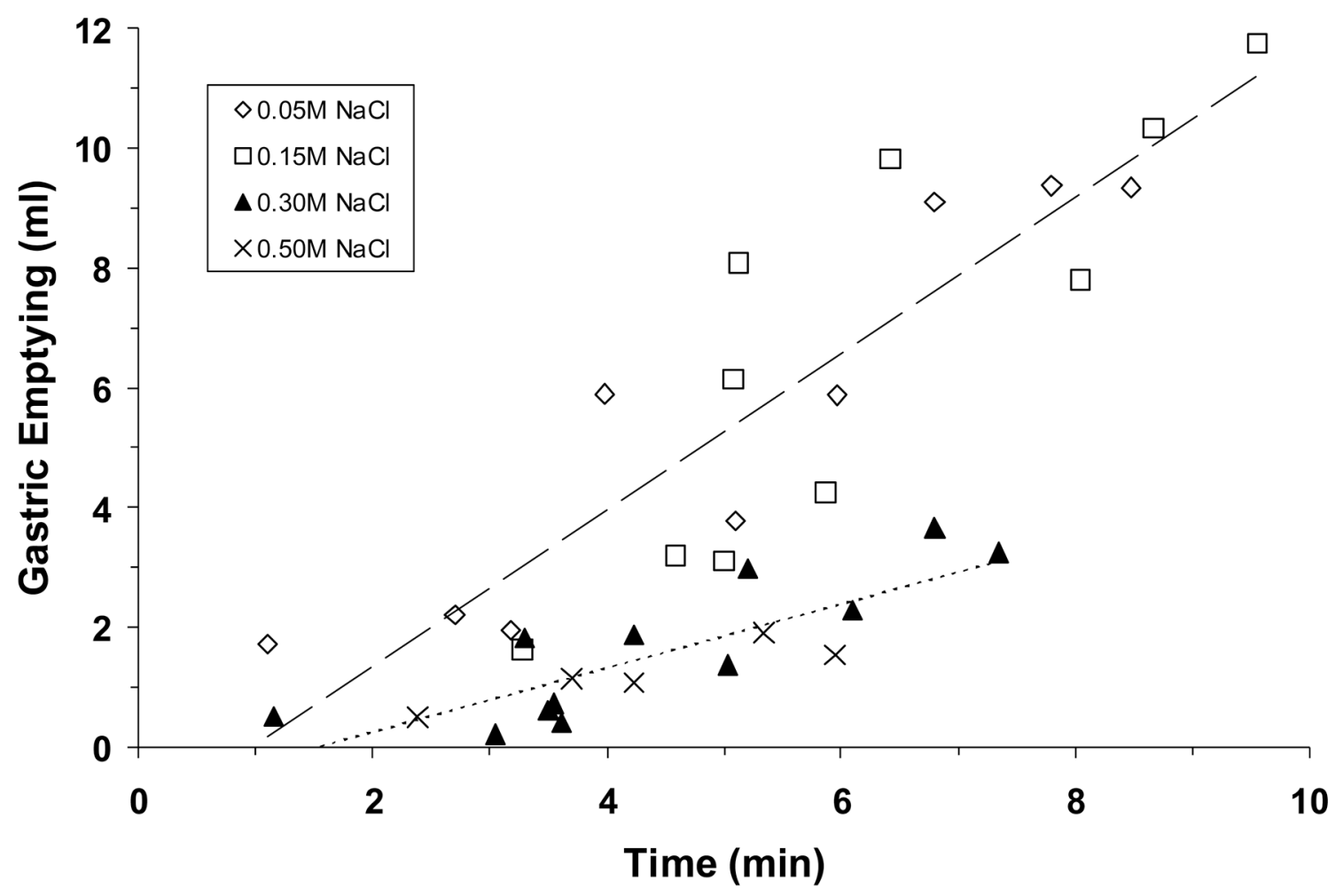

Physiol Behav. Author manuscript; available in PMC 2008 December 5. 
Figure 3B

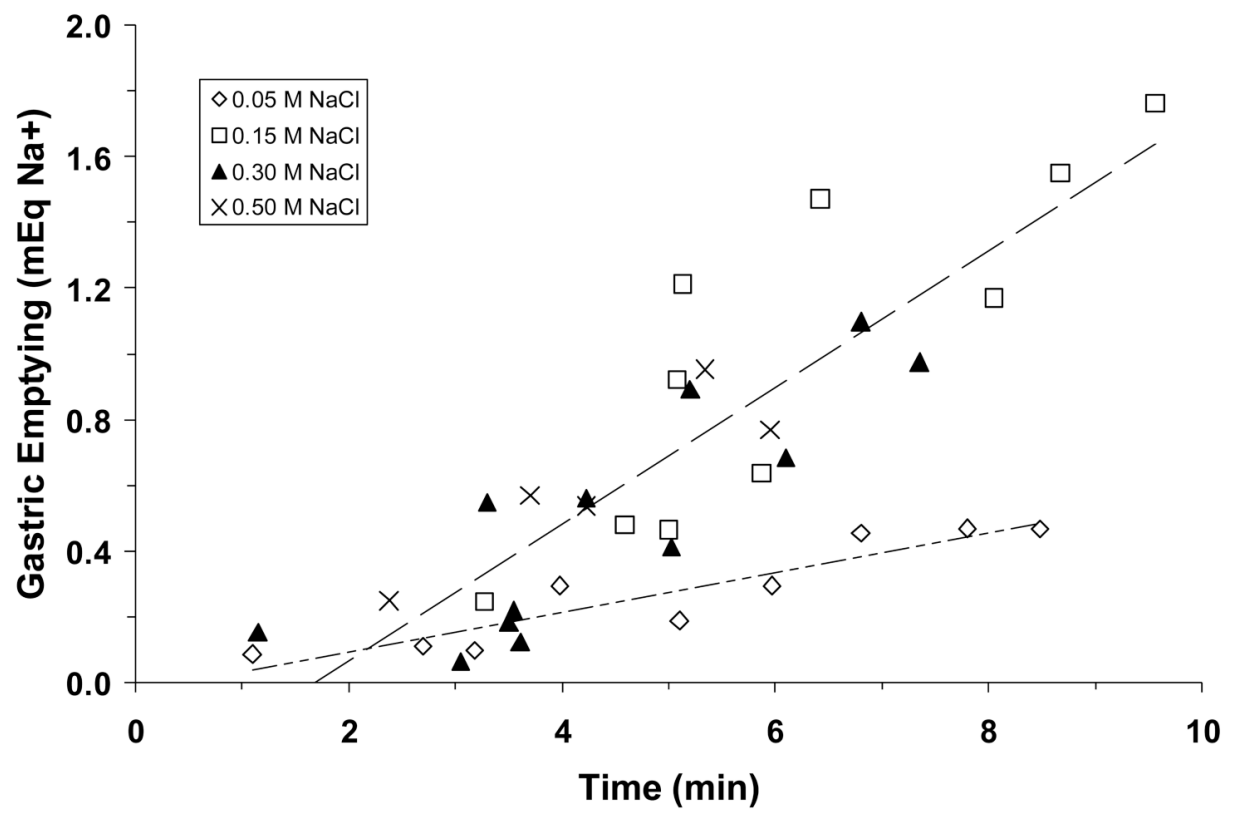

Fig. 3.

Estimated gastric emptying of ingested $\mathrm{NaCl}$ solution, plotted as a function of time spent drinking. Shown is emptying in $\mathrm{ml}(\mathrm{A})$ and in meq $\mathrm{Na}^{+}(\mathrm{B})$. Data are from the same adrex rats as in Figs. 2A and 2B. Symbols represent data from individual animals; dashed lines represent regression lines. Regression equations and correlation coefficients in Fig. 3A: for $0.05 \mathrm{M}$ and $0.15 \mathrm{M} \mathrm{NaCl}$ (upper line), $y=1.3030 x-1.2518, r=0.88, P<0.001$; for $0.30 \mathrm{M}$ and $0.50 \mathrm{M}$ $\mathrm{NaCl}$ (lower line), $y=0.5338 x-0.8171, r=0.83, P<0.001$. The rate of gastric emptying (in $\mathrm{ml} / \mathrm{min}$ ) was slower when the most concentrated $\mathrm{NaCl}$ solutions were ingested. Regression equations and correlation coefficients in Fig. 3B: for $0.05 \mathrm{M} \mathrm{NaCl}$ (lower line), $y=0.0605 x-$ $0.0296, r=0.93, P<0.001$; for $0.15 \mathrm{M}, 0.30 \mathrm{M}$, and $0.50 \mathrm{M} \mathrm{NaCl}$ (upper line), $y=0.2081 x-$ $0.3490, r=0.87, P<0.001$. The rate of gastric emptying (in meq $\mathrm{Na}^{+} / \mathrm{min}$ ) was similar regardless of which fluid was ingested except when the very dilute $\mathrm{NaCl}$ solution was consumed. Note that data from five rats that drank $0.15 \mathrm{M} \mathrm{NaCl}$ and had unusually high gastric solids (i.e., $>0.7 \mathrm{~g}$ ) were not included in these analyses. 


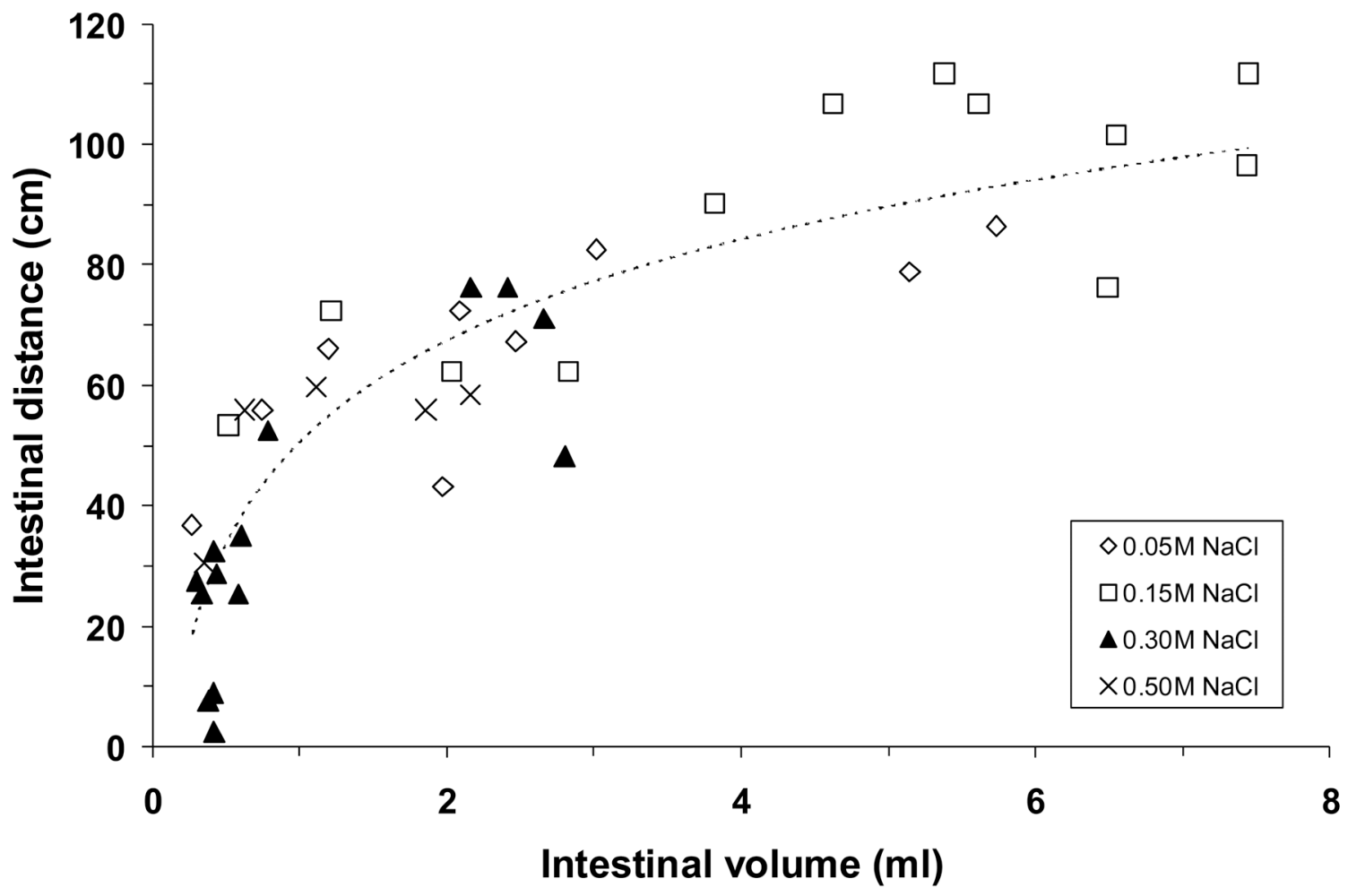

Fig. 4.

The distance that ingested $\mathrm{NaCl}$ solution traveled within the small intestine, plotted as a function of the volume of dyed fluid within the intestinal lumen. Data are from the same adrex rats as in Figs. 2 and 3. Symbols represent data from individual animals; dashed line represents regression line. Regression equation and correlation coefficient: $y=18.722 \ln (x)+58.041, r$ $=0.82, P<0.001$. The logarithmic regression line indicates that the increase in intestinal distance per volume began to diminish markedly once $0.5-1.0 \mathrm{ml}$ of fluid was in the small intestine. 


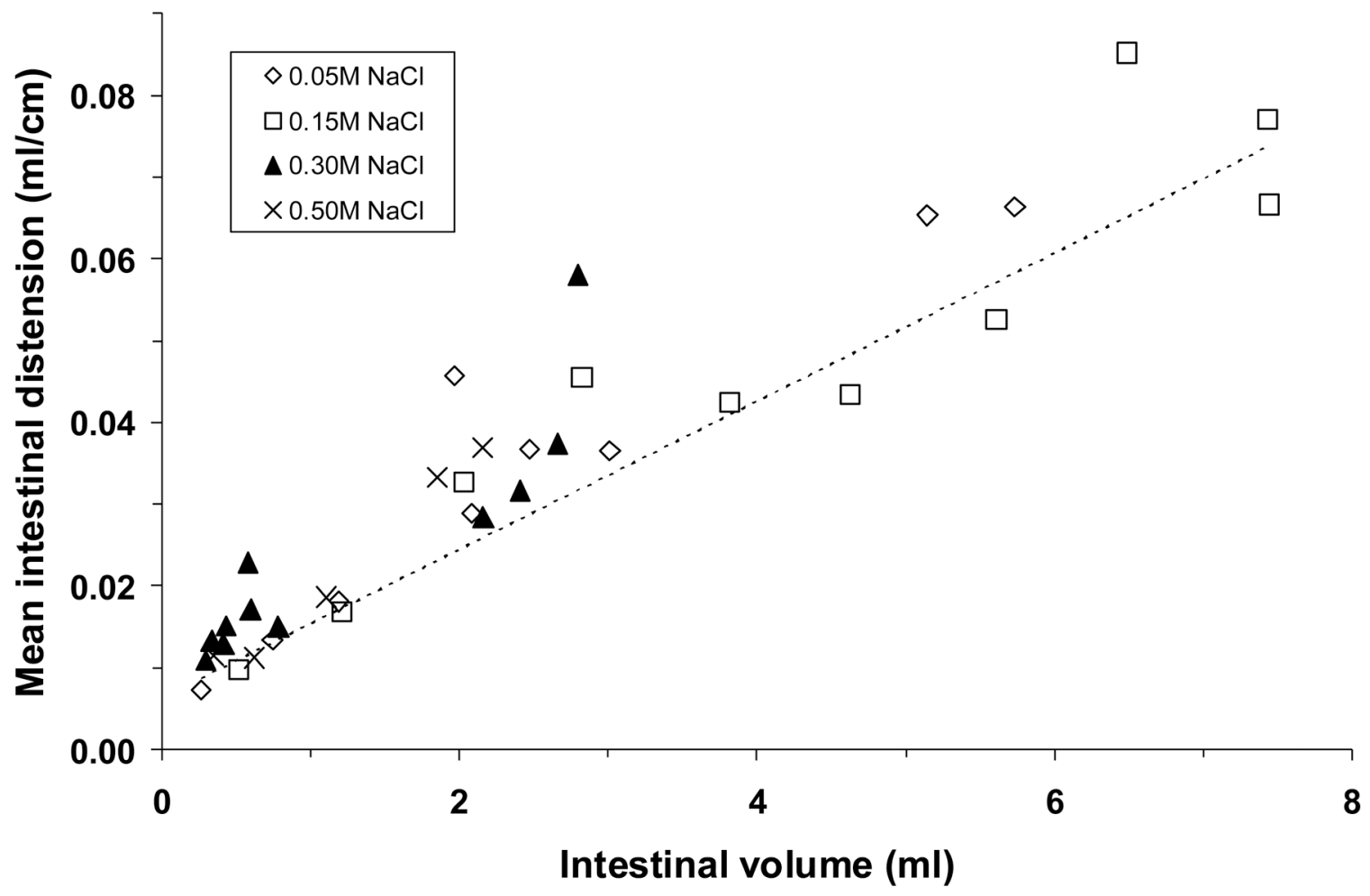

Fig. 5.

Mean distension of the small intestine that contained green-dyed $\mathrm{NaCl}$ solution, plotted as a function of the ingested fluid volume within the intestinal lumen. Data are from the same adrex rats as in Figs. 2-4. Symbols represent data from individual animals; dashed line represents regression line. Regression equation and correlation coefficient: $y=0.0091 x+0.0063, r=0.93$, $P<0.001$. Mean intestinal distension increased linearly in proportion to intestinal lumen volume. 


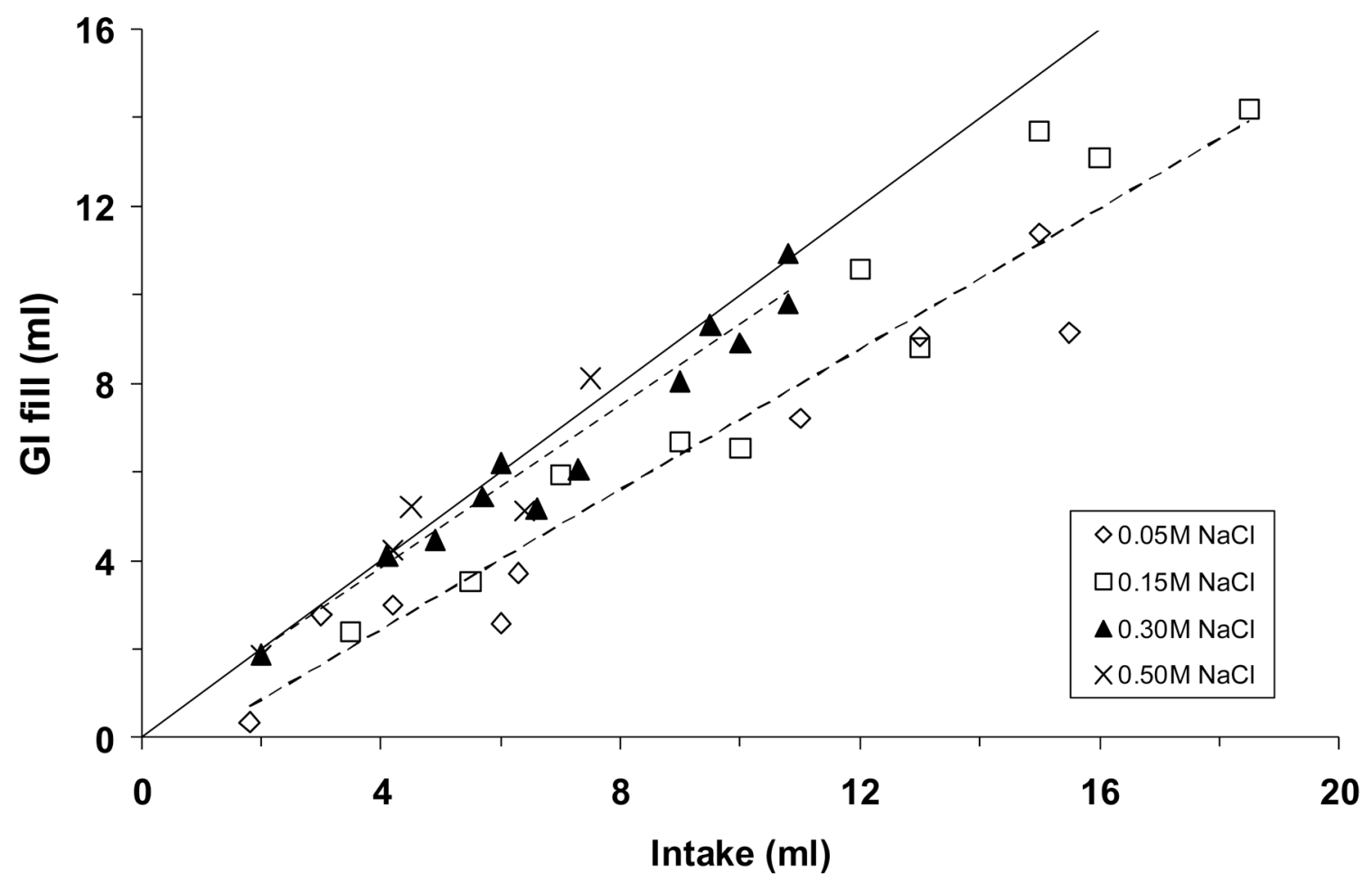

Fig. 6.

The sum of the measured fluid in the stomach and small intestine, plotted as a function of saline intake. Data are from the same adrex rats as in Figs. 2-5. Symbols represent data from individual animals; dashed line represents regression line, solid line represents the "no net absorption" line (i.e., $y=x$ ). Regression equations and correlation coefficients: for $0.05 \mathrm{M}$ and $0.15 \mathrm{M} \mathrm{NaCl}$ (lower line), $y=0.7918 x-0.7259, r=0.96, P<0.001$; for $0.30 \mathrm{M}$ and $0.50 \mathrm{M}$ $\mathrm{NaCl}$ (upper line), $y=0.8714 x+0.3116, r=0.97, P<0.001$. In each of these two groups, gastrointestinal fill was highly correlated with saline intake (both $P$ s <0.001). 


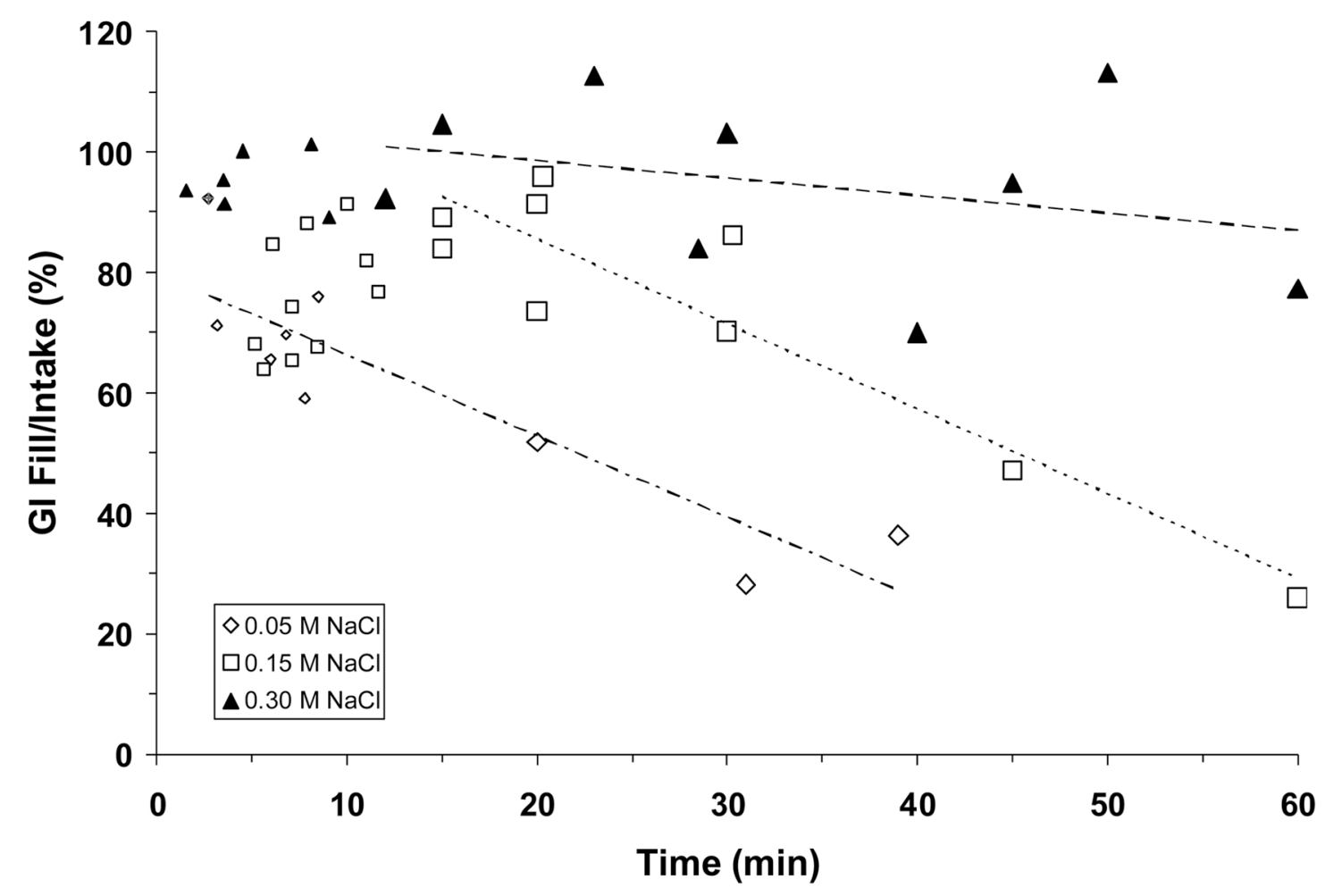

Fig. 7.

Gastrointestinal fill, expressed as a percentage of $\mathrm{NaCl}$ solution consumed in an initial drinking bout, plotted as a function of time during the 60-min test. Symbols represent data collected from individual animals either during (small symbols) or after the initial bout (large symbols), dashed lines represent regression lines. Regression equations and correlation coefficients: for $0.05 \mathrm{M} \mathrm{NaCl}$ (lower line), $y=-1.3485 x+79.8070, r=-0.89, P<0.001$; for $0.15 \mathrm{M} \mathrm{NaCl}$ (middle line), $y=-1.4083 x+113.68, r=-0.92, P<0.001$; for $0.30 \mathrm{M} \mathrm{NaCl}$ (upper line), $y=$ $-0.2908 x+104.41, r=-0.31, P=$ ns. Equation and correlation coefficient for $0.05 \mathrm{M} \mathrm{NaCl}$ includes data from the initial bout. GI fill decreased rapidly when adrex rats drank $0.05 \mathrm{M}$ or $0.15 \mathrm{M} \mathrm{NaCl}$ but it changed little when $0.30 \mathrm{M} \mathrm{NaCl}$ was consumed. 
Table 1

Systemic blood values in adrex rats drinking $\mathrm{NaCl}$ solutions.

\begin{tabular}{|c|c|c|c|c|}
\hline Group & $n$ & $(\mathrm{mEq} / \mathrm{L}) \mathrm{pNa}$ & (g/dl) pProt & (min) Time \\
\hline $\begin{array}{l}\text { Intact } \\
\text { No Access } \\
0.05 \mathrm{M} \mathrm{NaCl} \\
0.15 \mathrm{M} \mathrm{NaCl} \\
0.30 \mathrm{M} \mathrm{NaCl} \\
0.50 \mathrm{M} \mathrm{NaCl}\end{array}$ & $\begin{array}{r}11 \\
7 \\
8 \\
15 \\
12 \\
5\end{array}$ & $\begin{array}{l}143.3 \pm 0.4 \\
137.3 \pm 0.4^{b} \\
135.0 \pm 0.7^{b} \\
138.1 \pm 0.7^{b} \\
137.7 \pm 1.0^{b} \\
136.2 \pm 1.2^{b}\end{array}$ & $\begin{array}{l}6.1 \pm 0.1 \\
6.7 \pm 0.1^{a} \\
6.2 \pm 0.1 \\
6.4 \pm 0.1 \\
6.4 \pm 0.1 \\
6.7 \pm 0.2^{a}\end{array}$ & $\begin{array}{c}0 \\
0 \\
7.4 \pm 1.0 \\
6.5 \pm 0.7 \\
5.2 \pm 0.7 \\
7.3 \pm 0.9\end{array}$ \\
\hline
\end{tabular}

Adrex rats were given access to saline and water but did not drink water. Shown are systemic blood values and time of drinking (means \pm SE). Abbreviations: $n=$ number of rats, $\mathrm{pNa}=$ plasma $\mathrm{Na}^{+}$concentration, $\mathrm{pProt}=$ plasma protein concentration.

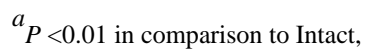

${ }_{P}^{b}<0.001$ in comparison to Intact 